\title{
The Rise of Student Social Movement: Case Study of \#GejayanCalling Movement in Yogyakarta
}

\section{Mahpudin ${ }^{1}$}

Departemen Politik Pemerintahan, Universitas Gadjah Mada, Yogyakarta, Indonesia mahpudinapud3@gmail.com

\section{Ardiman Kelihu²}

Departemen Politik Pemerintahan, Universitas Gadjah Mada, Yogyakarta, Indonesia ardiman.kelihu@mail.ugm.ac.id

\section{Mia Sarmiasih ${ }^{3}$}

Departemen Politik Pemerintahan, Universitas Gadjah Mada, Yogyakarta, Indonesia miasarmiasih96@gmail.com

\section{E-ISSN (2721-0642)}

Recieved:

February 112020

Revised:

March 272020

Accepted:

April 102020

Doi Number

10.37950/ijd.v2i1.2

\section{Abstract}

This paper discusses the rise of student social movements in response to the presence of a crisis of public legitimacy triggered by the failure of the government to carry out the functions of the state and failure to realize the welfare of society. The climax when the government and the parliament agreed to revise the rules regarding the authority of the Corruption Eradication Commission (Komisi Pemberantasan Korupsi, KPK) which was considered by many elements of civil society as weakening the KPK. This issue became the dominant discourse and triggered the presence of other issues and demands. The focus of this study is the \#GejayanCalling movement initiated by a number of students in Yogyakarta who successfully attracted the sympathy and support of thousands of students and various elements of civil society to take to the streets. This paper uses qualitative research methods with a case study approach. The data collection is done through primary data through interviews with key informants and secondary data through literature studies. The results of the study revealed that the \#GejayanCalling movement became massive and significant through the consolidation and political compromise undertaken by students in managing the movement to respond to public unrest marked by a crisis of public legitimacy towards the government. The protest was able to attract thousands of students because of the emphasis on the issue by overriding the role of certain figures, actors or organizations. Emphasis on issues rather than actors becomes an effective strategy in creating shared goals and collective action. Besides that, the use of social media as a repertoire of movements in framing issues is very contributing to strengthen demonstration.

Keywords: legitimacy, student movement, \#GejayanCalling 


\begin{abstract}
Abstrak
Penelitian ini membahas kebangkitan gerakan sosial mahasiswa sebagai tanggapan terhadap adanya krisis legitimasi publik yang dipicu oleh kegagalan pemerintah untuk menjalankan fungsi negara dan kegagalan untuk mewujudkan kesejahteraan masyarakat. Puncaknya ketika pemerintah dan parlemen sepakat untuk merevisi aturan mengenai kewenangan Komisi Pemberantasan Korupsi (KPK) yang dianggap oleh banyak elemen masyarakat sipil sebagai pelemahan KPK. Masalah ini menjadi wacana dominan dan memicu kehadiran isu dan tuntutan lainnya. Fokus penelitian ini adalah gerakan \#GejayanCalling yang diprakarsai oleh sejumlah siswa di Yogyakarta yang berhasil menarik simpati dan dukungan ribuan siswa dan berbagai elemen masyarakat sipil untuk turun ke jalan. Makalah ini menggunakan metode penelitian kualitatif dengan pendekatan studi kasus. Pengumpulan data dilakukan melalui data primer melalui wawancara dengan informan kunci dan data sekunder melalui studi literatur. Hasil penelitian mengungkapkan bahwa gerakan \#GejayanMemanggil menjadi masif dan signifikan melalui konsolidasi dan kompromi politik yang dilakukan oleh siswa dalam mengelola gerakan untuk menanggapi keresahan publik yang ditandai oleh krisis legitimasi publik terhadap pemerintah. Protes ini mampu menarik ribuan siswa karena penekanan pada masalah ini dengan mengesampingkan peran tokoh, aktor atau organisasi tertentu. Penekanan pada masalah daripada aktor menjadi strategi yang efektif dalam menciptakan tujuan bersama dan tindakan kolektif. Selain itu, penggunaan media sosial sebagai repertoar gerakan dalam membingkai isu sangat berkontribusi untuk memperkuat demonstrasi.
\end{abstract}

Kata kunci: legitimasi, gerakan mahasiswa, \#GejayanMemanggil

\title{
Introduction
}

This paper examines the phenomenon of student social movements which later drew attention in the conversation in public spaces. One student movement took place in Yogyakarta which achieved momentum on September 23, 2019. Various elements of Yogyakarta students at various universities took to the streets to protest against the government which was considered a failure in carrying out the idea of representation. This student movement is known as \#GejayanCalling. Gejayan is a protocol road used as a gathering place for mass action. This place was chosen because it has the same historical value of political struggle. In 1988, a prodemocracy civil movement gathered in Gejayan demanding the impeachment of President Soeharto while simultaneously echoing political change from authoritarian to democracy. There is romance from the past that is trying to be resurrected. But today, civil resistance is not against authoritarian regimes, but democratic regimes. 
The action of the Yogyakarta student movement which was then followed by a wave of other student protests in various regions was a response to various government policy products that were considered not in line with the spirit of democracy. The revised regulation of the Corruption Eradication Commission (Komisi Pemberantasan Koupsi, KPK) which has been ratified is considered as an effort by the government to weaken the KPK in an effort to eradicate corruption which often drags a number of political elites and public officials. The demand also extends to the issues of labor, land and human rights enforcement, whose findings are not accommodated in a responsive and accountable regulatory environment. In short, this wave of civic action initiated by students is a form of disappointment and dissatisfaction with the performance of the central government, especially in the function of making regulations that are pro-people.

Social movements are often organized by civil society in response to political situations that are considered contrary to the will of the public. Because it is organized from the grass root, social movements become part of informal political channels amid the lack of access to institutions holding authority, such as the government and other power institutions. Thus, social movements are always associated with the resistance of civil society in ensuring their legitimacy to a number of government policies. In this regard, Sidney Tarrow (1998: 4-5) then places social movements as a form of collective political resistance carried out by a group of people who have the same goals and solidarity to fight the elites and the authorities. In contrast, for example, Giddens (2013) sees social movements as collective actions to pursue certain goals or interests through social action.

Thus, the \#GejayanCalling movement becomes different from social actions such as Earth Day, Climate Change or other social services that civil society usually do. On the contrary, although both respond to political issues, social movements are also different from riot groups, acts of vigilantism, political parties, or certain political institutions. The reason is because it is done through "non-institutional methods" - like political institutions in general - whose purpose is not to obtain positions of power as bargaining to influence policy makers to take solutions that benefit them (Wilson, 1973).

Many previous studies have discussed the student movement in the context of social and political change. The student movement can not only be found in Indonesia, in various parts of the world, the student movement is mushrooming in various forms in accordance with the socio-political settings encountered. This confirms that students become one of the political actors to be reckoned with. Gencoglu \& Yarkin (2019) mentioned that the student movement in Turkey became one of the important keys for the opening of the democratization tap. The student movement incorporated in Student Collectives (SC) consistently opposes the government regime which is motivated by a crisis of representation where democracy does not work as it should. SC considers that the elections that have been 
implemented in Turkey are only limited to the replacement of the political elite without being followed by significant socio-political changes.

Ahmed (2019) photographed the protest of black students at the University of Cape Town (UCT), South Africa. In mid-2015 there was a wave of massive protests called \#RhodesMustFall. Students protest the existence of the statue of Cecil Rhodes as a magnificent monument located in the campus yard as a form of respect for British colonialism and supremacy of the white class. In the view of students, the statue is not worthy of standing on campus because it is not relevant in the spirit of decolonization. In addition, South Africa is also known for its protest in the \#FeesMustFall movement as a campaign to create a more democratic and inclusive education curriculum. This is because several universities in South Africa have not been able to overcome the problem of poor students and workers (Luescher, Loader \& Mugume, 2016). Student protests demanding reform of educational institutions also took place in Chile (Gonzalez, 2016; Bellei, et al, 2014). In general, students reject campus and government policies that liberalize and commercialize in the education world because they are considered to only benefit the upper-middle class. While poor students are increasingly difficult to access education.

Chan (2016) examines the Hong Kong student movement known as the "Post Umberella Movement". The movement that emerged in 2016 was a strong reaction from students to mainland Chinese government intervention related to the Hong Kong Special Administrative Region. This student movement sharpens radical localism which is characterized by high socio-political awareness among Hong Kong students. This movement continues to be maintained to guarantee the political social rights of Hong Kong women.

In Indonesia, the student movement is often associated with the events of 1998 marked by the overthrow of the authoritarian Suharto regime. In fact, if examined further, the student movement in its history helped color Indonesian politics. During the period of independence and the old order, the student movement was divided because of very sharp ideological differences between the movements. In contrast to Suharto's new order, the student movement seemed to find momentum to form the same vertex of struggle as against hegemony and the domination of Suharto's authoritarian rule. Jamizah (2013) took the student protest action during the Soeharto era known as the Malari incident. The protest was carried out in response to poor education governance and the massive corruption of public officials. This resistance to Seoharto was followed by riots, vandalism and arson which caused several deaths and injuries.

The rise of reform in 1998 marked by the fall of Soeharto was inseparable from the struggle of the student movement in various regions. But since the reform era until now, the massive student movement has hardly emerged. The ups and downs of the student movement in carrying out resistance and protest against the government were deemed to have failed in carrying out the duties and functions of the state. The student movement is only interconnected on specific and particular 
issues which are limited to narrow area coverage. Taufik (2014) for example portrays the student resistance movement towards the capitalization of education initiated by extra-campus organizations at Semarang State University. While Chamadi, et al (2019) placed Islamic student movements in Purwokerto such as the Islamic Student Association (Himpunan Mahasiswa Islam, HMI), the Indonesian Islamic Student Movement (Pergerakan Mahasiswa Islam Indonesia), Muhammadiyah Student Association (Ikatan Mahasiswa Muhammadiyah) and the Indonesian Muslim Student Action Unit (Kesatuan Aksi Mahasiswa Muslim Indonesia) in the typology of movements that included political movements, academics, religious propaganda and entrepreneurship. That is, the national student resistance movement involving thousands of masses plunged into the streets hard to find in the 1998 student movement. However, this condition was different in 2019 where there was a massive student movement after a long sleep. Students in various regions simultaneously held protests and demonstrations against the performance of the Jokowi government and the political elite in Senayan who were considered to have hijacked the spirit of reform.

This massive student movement, one of which took place in Yogyakarta with a very well-known rhetoric by \#GejayanCalling. This Yogyakarta student action was centered at the Gejayan T-junction. Previously students held long marches from the north, west and south. There are three predetermined gathering points, namely the Gadjah Mada University (UGM) Roundabout, Islamic State University of Sunan Kalijaga T-junction, and the Main Gate of Sanata Dharma University. The period has arrived and filled many of the designated gathering places starting at 10:00 to 12:00. The cheering and singing of the spirit of a child typical movement is endlessly echoed. This student action lasts for about 5 hours and ends in the afternoon. A crowd of thousands of actions forced the police to divert the flow of vehicle traffic. In addition to the longmarch, this action was followed by a signature activity on a wide-spread banner. The participants took turns stroking ink on the available banners. Some of the demonstrators also demonstrated sleeping on the asphalt road for a few minutes as a symbol of the demise of democracy in Indonesia. The pulpit was prepared for anyone who wanted to express their opinions and vent their protest. The question that arises is how the \#GejayanCalling movement is formed. Why the \#GejayanCalling is successful in attracting the sympathy of thousands of students to take to the streets.

\section{Theoritical Frameworks}

\section{Social Movements and Legitimacy: Theoretical Review}

The student movement in its development experienced dynamics and transformation in accordance with the social settings and political systems that were developing at that time. The style of the regime also influenced the direction and form of the student movement. This dynamic student movement often leads us to 
debate about the direction of the student movement which dichotomizes on two things: moral movements or political movements (Usman, 1999). The first view states that the student movement as a moral movement that puts students as the main force as a driver of change in the performance of the government in carrying out the idea of representation and mobilizing public anxiety as an instrument to suppress and demand the government in its function to serve the public. Therefore, this view sees students must be outside the structure and bureaucracy of the government. While the second view mentions that the student movement can be transformed into a political movement on the basis of strengthening the struggle of students in fighting for people's aspirations and demands. Therefore students must be placed as real power in the political arena by becoming involved in formal power.

Apart from this debate, this paper places the student movement as part of a social movement. Giddens (1993: 642) sees social movements as collective actions to achieve common goals outside the established institutional arena. Not much different, Tarrow placed social movements as a political resistance (contentious politics). For the purposes of this study, the social movements referred to hereinafter will be placed in the political context of resistance. Contentious politics as a movement has four characteristics, namely collective challenge or enemy, common purpose, social solidarity, and sustained interaction. (Tarrow, 2011: 8).

McAdam, Tarrow and Tilly (2001) offer concepts and theories about movements more dynamically by making indicators of political opportunities structure, mobilization structure, framing and repetoir as operational subjects to explain resistance movements. Therefore, this paper intends to make the various perspectives available as an integrated analysis in understanding the patterns, forms and dynamics of the emergence of social movements as a political resistance. Repertoire and framing aspects are important for further review. Repertoire is a collection of tools or instruments that can be used by a group of people in achieving their desires, as a means of interaction between groups. Repertoire is a way or strategy by which people can engage in collective action in carrying out political resistance (McAdam, Tarrow, and Tilly: 2001). The form of repertoire varies according to the needs and the political context at hand. Repertoire is a resource used by chords to claim a resistance movement. In general, repertoires are packaged in such a way that actors become collective identities that can be accepted and are relatively easy to do by the community without the need to incur costs or take large risks.

This form of resistance itself is a collective incentive for some people in certain situations to challenge opponents by using incentives that underpin their networks of trust and solidarity. Repertoire becomes important to see why certain resistance actions take certain ways and forms of action and why changes occur. Some examples of forms of repertoire as forms of resistance action such as street demonstrations, strikes, damaging public goods, issuing petitions, forming resistance tags on social media and so on. 
Repertoire used in the politics of resistance often includes framing efforts to urge, encourage and intensify resistance. Framing is a process of framing, collective interpretation and social construction to form an awareness that people who feel disadvantaged must be actively involved in collective action to change circumstances. Therefore, expressions of disappointment continue to be exploited to produce a collective identity. This identity eventually forms the demarcation line between "us" and "them" in the conflict structure. "We" are defined as the public who feel disadvantaged and suffer from social political marginalization, while "they" are interpreted as corrupt and corrupt enemies or opponents that are the cause of public injustice and misery (Tarrow, 2011: 32).

Actors continue to frame political issues and narratives that are considered relevant in establishing resistance movements and fighting for public discourse. Framing requires media as an instrument to form discourse. The media used are diverse such as pamphlets, books, printed media, advertisements, campaigns, internet, social media (Facebook, Instagram, Twitter) or public places as a medium for debate such as in meeting rooms, coffee shops, and so on. \#GejayanCalling movement use social media as a repertoire of resistance and help in the process of framing issues to attract massive student support.

Protests are often associated with a crisis of citizens' legitimacy to the government. Referring to the definition of Heywood (2014) legitimacy is a quality that turns power into legitimate authority. Legitimacy is important to create political stability, enable the reduction of coercive means and improve the quality of welfare. According to Ramlan Surbakti (1992) a crisis of legitimacy can occur in response to public disappointment with the government because of broken promises for welfare and changes in the socialization of authority. Ineffective government performance can also trigger a crisis of legitimacy (Lipset, 1993). A wave of student protests is a sign of government being hit by a crisis of legitimacy.

\section{Research Methodology}

This study uses qualitative research methods with a case study approach. The case study approach was chosen because it was considered relevant in an effort to explore social phenomena in a limited and specific way through in-depth and detailed data collection (Creswell, 2014). The case in question is a social movement of students in Yogyakarta, known as the \#GejayanCalling. The data collection process uses two things namely primary data and secondary data. Primary data was carried out through interviews with informants who were considered relevant in this study. The selection of informants is based on the purposive method, namely the selection of key informants who are considered masters of the problems associated with this research. While secondary data is done through literature studies related to student social movements that are considered relevant and can help in enriching the 
analysis. Researchers also made observations during the Yogyakarta student protest on September 23, 2019.

In analyzing data in qualitative research the case study approach is carried out with several stages including organizing data, reading data and discovering the importance of each data obtained, describing cases and their context, classifying and interpreting data before finally presenting and narrating existing data using tables or images that are tailored to the needs of data presentation (Creswell, 2014).

\section{Result and Discussion}

\section{Political Consolidation and Compromise: A Point of Action for Demonstration}

The protests of Yogyakarta students initially departed from a small discussion conducted by several UGM students at the UGM Bonbin Canteen. This place is often used by student activists to dialogue on public issues. The existence of canteens, angkringan and various other places serve as public spaces to discuss ideas and discourse brought by student activists to be discussed and debated so as to reach an understanding. From this understanding will result in a collective agreement and truth to take an action through understanding intersubjectivity among students. At that time, there was student anxiety related to a number of bills that were being deliberated by the Parliament and the Government which were considered problematic. One of the most problematic about the KPK Bill which reaps a lot of polemic and rejection from various elements of civil society because the KPK Bill is deemed to have weakened the anti-corruption institution in eradicating corruption through the castration of a number of KPK authorities. In addition to the KPK Bill, a number of other regulations such as the Criminal Code Bill and a number of other issues have also succeeded in stealing the attention of students.

This casual conversatiom between student activists then began to become a critical discussion by involving various groups of students and elements of civil society. Finally, several student activists from various universities agreed to meet to discuss seriously a number of issues that were becoming public anxiety. As a result, the student actors involved became widespread. To launch the strategy, various groups and organizations of students and civil society have consolidated massively. From here various meetings began frequently. Negotiations between actors in managing a protest are inevitable. The consolidation between these actors finally agreed to form a collective movement under the name of the "People's Alliance of Movements" (Aliansi Rakyat Bergerak) by setting the \#GejayanCalling jargon on various social media.

Students and civil society groups as intermediary actors carry out the process of consolidation and negotiation. Noted several actors involved include: student activities on various campuses in Yogyakarta (UGM, Sanata Dharma University, Islamic State University of Sunan Kalijaga), Labor Organizations, Feminist Groups, Nusantara Indigenous Peoples Alliance (Aliansi Masyarakat Adat Nusantara, 
AMAN) and youth organizations (GMNI, LMND, KAMMI, HMI) . These groups agreed to make their respective coordinators and make a committee. Consolidation between groups was completed with the introduction of the "People's Alliance of Movements"

After group or actor consolidation, the next step is to consolidate issues. The central issue that unites these various actors is related to the weakening of the KPK and the Criminal Code Bill. However, there are particular issues brought by each student activist group. As an example of AMAN bringing up the issue of land politics and customary rights, feminist activists focus on the issue of gender inequality and discrimination against women. This then explains the emergence of seven demands which not only focus on the issue of weakening the KPK and the Criminal Code Bill. The seven demands are the result of various consolidations and compromises between student activist groups. This strategy is used to streamline the movement, mobilize the masses by expanding the issues and involvement of various elements of civil society groups.

The seven demands of students in the protest action at \#GejayanCalling are: 1) Urging a delay to review the problematic articles in the RKUHP; 2) Urge the Government and Parliament to revise the recently passed KPK Law and reject any weakening of efforts to eradicate corruption in Indonesia; 3) Demand that the State investigate and prosecute the elites responsible for environmental damage in several regions in Indonesia; 4) Reject the problematic articles in the Labor Bill which do not favor workers; 5) Reject the problematic articles in the Land Bill which are a form of betrayal of the spirit of agrarian reform; 6) Urging the ratification of the Bill on the Elimination of Sexual Violence; 7) Encourage the democratization process in Indonesia and stop the arrest of activists in various sectors.

One of the results of an actor's compromise that is also important to discuss here is the emergence of a political agreement between the actors of the movement not to use various symbols and flags that represent certain groups of organizations. This is done to dismiss the notion that social movements are mobilized by certain actors or organizations. These student activists want to emphasize issues rather than actors. This strategy was also carried out to eliminate the various barriers of the various groups and organizations involved. But it should also be seen that the agreement on the prohibition of carrying organizational attributes was taken to avoid the domination and hegemony between groups that resulted in the weakening of the movement due to fragmentation between actors.

In a political community which involves various actors, of course the potential for dominating and hegemony done by certain groups to other groups is a necessity. Awareness of these conditions, the various groups and organizations involved agreed not to accentuate the actors but rather the issues. There is no other choice not to agree or withdraw because the groups and organizations are trying to take advantage of opportunities from the emergence of public unrest over issues regarding the weakening of the KPK and the Criminal Code Bill. When certain 
groups and organizations cleanly fight for specific issues, they will not succeed in winning the people's sympathy because not all people have the same anxiety about the issues and agendas they bring. So engaging in the student movement as a response to the issue of weakening the KPK and the Criminal Code Bill which has a number of rubber articles is the only strategy by continuing to bring particular issues through a process of consolidation and negotiation between actors.

In an interview with our informant mentioned that the rise of seven demands in the \#GejayanCalling action was not free from compromise, consolidation and the results of attraction between movement actors from both students and non-students (civil society). Among activists involved in the consolidation process, not all were willing to include the issues and demands brought by each movement activist in the demonstration. For example, efforts to include issues on feminism and the Elimination of Sexual Violence Bill (Penghapusan Kekerasan Seksual, PKS) have been widely rejected, especially from activists who have Islamic platforms, such as PMII, KAMMI, PMI. They refused on the pretext that the issue of feminism and the PKS Bill contradicted their ideological values and lines of struggle. Gadjah Mada University students who have a background in the KAMMI organization are among those who are counter to the issue of feminism and the PKS Bill. However, due to the many pressures and political intervention from various other movement activists with the aim of utilizing the momentum and ensuring the movement, the counter parties finally began to relax their attitudes and were willing to include the PKS Bill issue in the seven demands for student protest actions. In other words, the inclusion of the PKS Draft Bill is actually not entirely pure because there is a common understanding of the importance of the issue of feminism and gender equality among activists but rather on the larger goal of optimizing the movement which will have a strong impact on the government (Interview with Pipin Jamson, November $29,2019)$.

Besides the issue of the PKS Bill, the issue of Papua also found a tough road. Some groups involved in the consolidation and compromise of the \#GerjayanCalling movement initially acted counter to the excuse of including the Papuan issue as tantamount to supporting the discourse of self-determination rights related to the will of Papua who wanted to separate from the Homeland. But then the ongoing negotiations shifted not to the emphasis related to separating from Indonesia or regional expansion but rather to uncovering cases of human rights violations in Papua and demanding that the government stop the criminalization of human rights activists, many of whom were responded by the police when organizing the mass in a demonstration. Finally, the issue of upholding human rights was incorporated into the seven demands of the \#GejayanCalling action.

The point to be conveyed here is that the rise of the seven demands of the Yogyajarta student demonstration in \#GejayanCalling do not necessarily appear automatically. The seven demands are the result of a process of negotiation and political compromise among movement activists in responding to the emergence of a 
crisis of public legitimacy and a decline in public confidence in the government. The dominant issue in this movement is related to the weakening of the KPK, but to make the movement more effective, other issues which are also considered to be a problem of the government are included in demonstrations without eliminating each other's issues. In other words, the issues brought by each movement activist worked together with other movement activists and issues by trying to form a common enemy, namely a government that was not successful in carrying out the functions of the state and realizing public welfare. The famous jargon echoed by students that reform has been corrupted by the state.

This became interesting because the \#GejayanCalling movement in Yogyakarta which was then followed by a wave of resistance by thousands of students in a number of regions became a new history in the spirit of post-New Order social movements. Because so far social movements or similar demonstration actions are not as massive as the current student movement. Even though protests involving thousands of masses and even millions of masses have taken place such as the labor movement every day before labor days or Islamic movements that are bound by volumes, but the existing movements only involve particular issues with groups or organizations that are single (homogeneous). In contrast to the student movement which consists of various civil society groups with a divergence of issues and demands can go together to form an alliance in protesting the government. The student movement was able to demarcate the issue of sectoral egos internally within the movement activists who had been a problem in the social movement discourse. All that can not be separated from the compromise and solid consolidation between actors and activists on behalf of the People's Movement, which in the context of Yogyakarta is more popularly known as \#GejayanCalling.

\section{Social Media as a Campaign Instrument}

After the consolidation between the activist groups movement was completed with an agreement of seven demands that would be taken when the protest took to the streets, the next step was to carry out campaigns and propaganda with the aim of mobilizing the masses to be involved in the protest or at least the public was aware of the agenda being planned by student activists. Campaigns and propaganda are important to provide public knowledge and awareness that the issues or demands that have been formulated by student activists are public problems. One strategy chosen by student activists is to campaign for protests through the use of social media networks such as Twitter, Instagram, and Facebook. Each movement activist consisting of various campus organizations creates agitation content that will be uploaded on social media. There is a special team agreed by the movement activists to create content designs. The contents of agitation that are the greatest on social media use confrontational rhetoric and statements and are packaged in such a way as to target the public, especially among students or young people who are the main 
segmentation. The rhetoric of the \#GejayanCalling movement, \#CorruptedReform, \#WeakenedKPK and various other hashtags related to seven demands for protest.

Social media seems to be one of the important instruments and greatly contributes to campaigning for the movement. The flood of students taking to the streets cannot be separated because of the influence of social media. Information received by students can easily be passed on to other students only by re-sharing content that is spread on social media. In particular, student activists involved in the People's Alliance Movement made social media accounts such as Instagram with the "People's Alliance Movement" account which currently has followers of 22 thousands social media users.

Twitter has become a very effective propaganda tool in agitating the public. When the Yogyakarta student protest took place on September 23, 2019, \#GejayanCalling had a chance to occupy the top position on Twitter as a tranding topic. This student protest almost happened simultaneously in various regions in Indonesia. If we look at the distribution of Twitter users' data in Indonesia who carry out tweets related to protest actions, the number of tweets varies from region to region. The results of analysis from the Big Data Department of Government Politics, Faculty of Social and Political Sciences UGM (Jamson, 2019) by collecting tweets on Twitter from 9 September to 14 October 2019 related to student actions in various regions in Indonesia showed that of 235,811 pieces collected with $51,310(51,310)$ $21.8 \%$ ) detected. In that time span, the most number of tweets reached its peak on September 21-23, 2019, with more than 20 pieces of tweets related to student protests. Yogyakarta area occupies the top position of internet users who do tweeting.

Figure 1: Calculation of the number of tweets per day related to student protests in the range 9 September to 14 October 2019

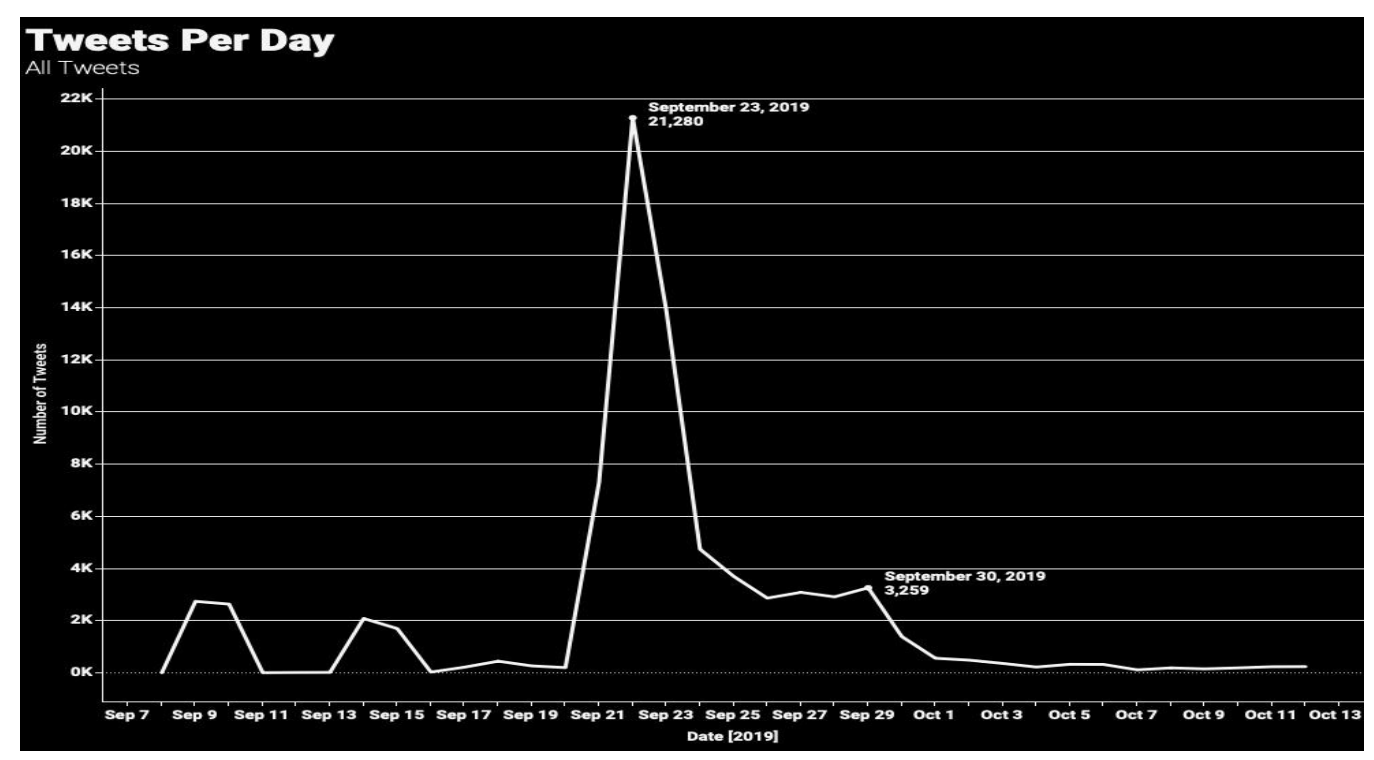

Source: Big Data DPP UGM (Jamson, 2019) 
Figure 2: Number of tweets per province

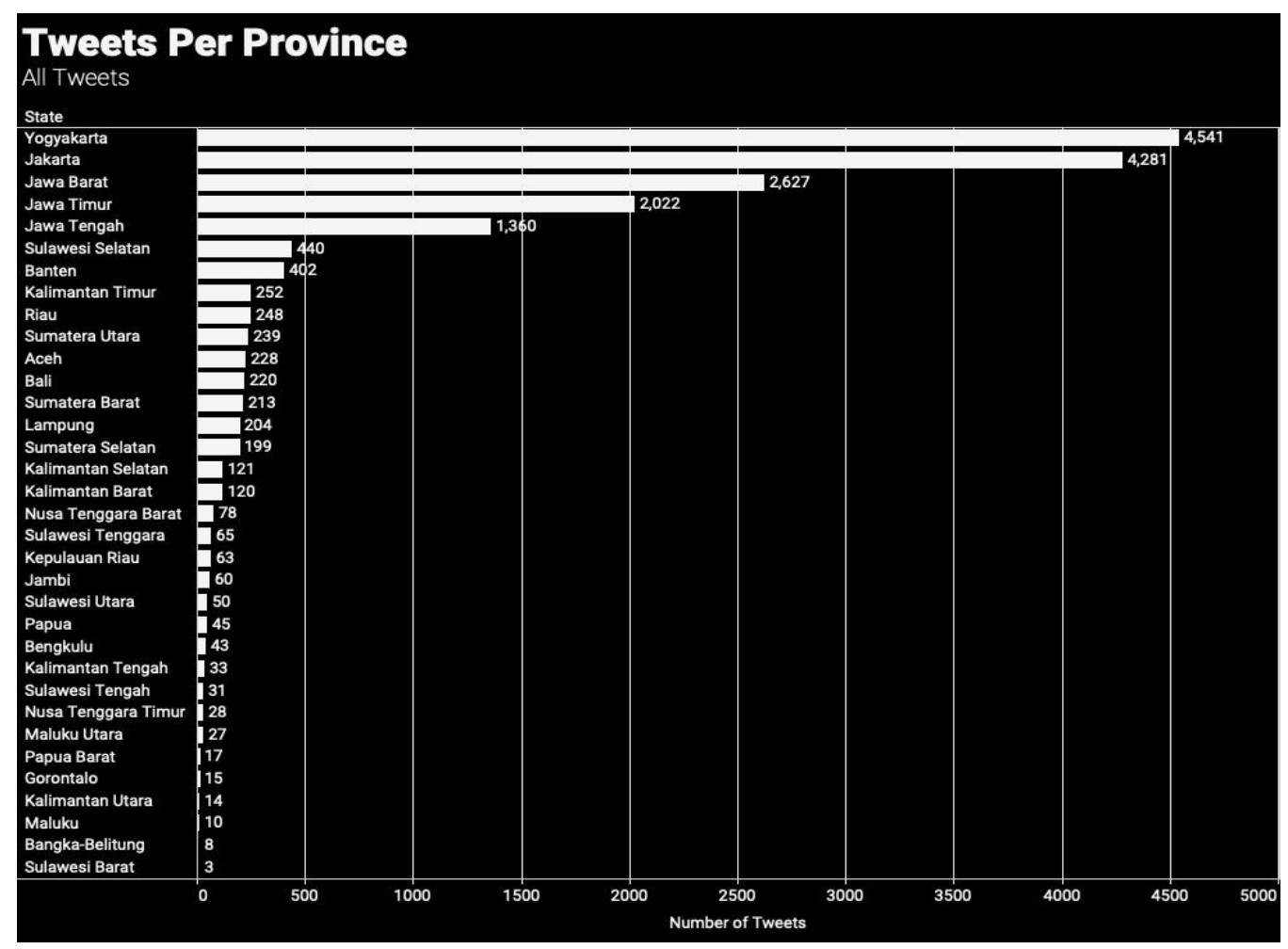

Source: Big Data DPP UGM (Jamson, 2019)

The data above confirms that social media has become a very effective repertoire in mobilizing the masses and raising issues into the public sphere. The mass protests of students in Yogyakarta which were then followed by protests in various regions including Jakarta could not be separated from the influence of social media. That is, activists of the student movement are very keen in taking advantage of opportunities that exist through open access to information and the size of internet users in Indonesia. So that conventional methods through political speech in the open field are being abandoned, although they are still important in every momentum of the civil movement.

Nevertheless, social media has also become a battleground for discourse. Many parties or say government buzzer is trying to deflate student protests so it does not become a threat to the government. This was very much realized by the activists of the student movement following a lot of hoax news on social media with various accusations such as the issue that the student movement was ridden by politicians especially the government opposition to the issue of wanting to overthrow the Jokowi regime. Responding to the circulation of this hoax, student movement activists counter issues with narratives trying to clarify allegations of 
issues thrown into the social media space (Interview with Endang on October 29, 2019)

\section{Repressive regime: Efforts to Reduce Demonstration Waves}

As was mentioned earlier that among the actors involved in the movement "People's Alliance of Movements" to consolidate and compromise in managing student movements. Compromise occurs in two dimensions: vertically and horizontally. Vertical compromise involves political elites with student movement actors. The wave of protests that took place in Yogyakarta and followed by various other regions has made the government have to take political action. This is needed to reduce the occurrence of larger mass movements so as to trigger a crisis of legitimacy and political stability. In response, the government used various methods to ensure that the student protest movement remained under control.

President Jokowi through the Ministry of Research and Technology and all bureaucratic and security devices began to intervene the movement. On September 23, 2019 during the Yogyakarta student protest, three large campuses in Yogyakarta issued a circular containing the prohibition of students from engaging in demonstrations and were not responsible for any consequences resulting from the demonstration. The campuses that issued the circular were Gadjah Mada University (UGM), Sunan Kalijaga State Islamic University, Yogyakarta State University, Duta Wacana Christian University (UKDW) Yogyakarta and Sanata Dharma University. The circular was signed directly by the respective chancellors. In addition to banning students from engaging in demonstrations, the campus asked the internal campus student organizations to withdraw from the demonstration. The rector who issued the circular reasoned that the demonstration was unclear because it was unknown who was responsible.

If it is examined the issuance of circulars from various campuses in Yogyakarta confirms the existence of strong allegations related to government intervention through Kemenristekdikti. This is reinforced by the emergence of statements from Mohammad Nasir, Menristekdikti in various media who called on the campus not to give permission for students to engage in demonstrations. Nasir even threatened to impose sanctions on the chancellor and campus who were found to encourage students to take to the streets (www.nasional.kompas.com). Nastir's political decision cannot be separated from the request of President Jokowi (ibid). Not only that, the government began to use repressive means through the police to quell mass actions.

The government's political actions are actually a deadlock from the negotiation process and compromise between the student movement actors and the government. Actors of the student movement cleanly demanded the government to cancel the KPK Bill and the Criminal Code Bill. The government once invited representatives from the student movement to the palace. But the invitation was declined by students and requested an open meeting to avoid the appearance of 
negative sentiments towards the student movement. While the government has an interest to immediately reduce the larger demonstrations because it will lead to a crisis of legitimacy and social chaos. Finally, the government took a political decision to temporarily suspend the Criminal Code Bill. However, the KPK Bill has been dished out and enacted. The postponement of a number of discussions and ratification of the bill carried out by the government and the Parliament was also followed by a decrease in the intensity of student demonstrations in various regions including in Yogyakarata.

\title{
\#GejayanCalling as Social Movement
}

In describing the \#GejayanCalling movement in Yogyakarta, social movement is important to understand as collective solidarity which not only opposes a number of political decisions from the government while also questioning the public legitimacy of a number of those decisions. In democracies, even though these government decisions are carried out according to political procedures, they should be supported by the public as proof that the decision has strong public legitimacy. In this context, social movements must be understood as middle ground/intermediary which not only brings together the formal political procedures of the government and the public interest, but also has its own function to consolidate. This is in line with what was conveyed by one of the movers of the \#GejayanCalling in an interview:

\begin{abstract}
"Even though the \#GejayanCalling movement is impressed suddenly without preparation, but the process to find the middle ground is through long negotiations and consolidations. Because many actions only prioritize sectoral organizations or specific issues and each competes with each other, there is no initiation for collaboration. For example including two issues such as Papua and the PKS Bill "(interview with Pipin Jamson on 29 November 2019).
\end{abstract}

As for social movements, the consolidation of movements becomes an important element in order to strengthen the protests or messages to be conveyed. There are at least three important elements carried out in the movement including: (1) organizing groups of movements in a sustainable manner against the authority being targeted, (2) forming a movement alliance that fits the objectives of the movement involved in social action, petitions, propaganda in the media, or demonstrations, and (3) include movement representatives in negotiating the goals of the movement (Tilly, 2014). By referring to the elements of the movement, \#GejayanCalling also adopts the same movement elements. Either by organizing social movements in a sustainable manner, forming alliances and action committees, mobilizing the masses such as, students, students, civil society, NGOs, social communities, demonstrations, and amplifying narratives on social media. 
Historically, social movements have always stretched from time to time, depending on the socio-political setting. These social and political settings affect the spectrum of social movements (Hikmawan, 2020). Previously, during the Cold War, there are always political ideology conflicts which also have implications for the style of social movements. Several protests then emerged and were often preceded by a number of movement figures. They include, like, Mahatma Gandhi in India, Sukarno in Indonesia, Che Guevara, and Fidel Castro, Frad Hampthon, Marthin Luther Jr. Most of them are movement figures who appear to represent the struggle of the socialist/third world countries which at that time faced political ideology with liberal/first world countries (Hikmawan, 2020). After that, the political ideology setting of the two poles slowly melted, followed by a change in the spectrum of social movements from the old social movements based on figures to new social movements based on shared issues without a cult of figure. In other words, the presence of movement figures is not always apparent.

The emergence of a social movement without a main figure is a combination of resistance to capital and a commitment to participatory democratic openness that rejects centralized discipline (Ojeili \& Hayden, 2006: 33-37). Movements without this main figure have the advantage of being diffused and accepted and consolidated by various variants of the group. They come from different groups by bringing one value together. Neo-Marxist thinkers such as Michael Hardt \& Antonio Negri (2004) call this movement pattern a model of the multitude of struggle movement. Multitude means the appearance of various political subjects in expressing their protest against a hegemonic (empire) and oppressive power.

\#GejayanCalling is a new social movement model, which is not rigidly organized, represents new issues and interests, and is based on the future (Singh, 2010: 109-132). This can be seen from the appearance of various actors who pushed the issue called Corruption Reform. The choice of this issue responds to the government's political decisions through a number of bills which are considered problematic because it is more pro-oligarchic and disadvantages the public. To encourage the movement of public issues, the social movement is more called themselves as the People's Alliance of Movements to consolidate a number of segments of the movement with representations of different issues (Hikmawan, 2020). The naming of the alliance was also deliberately chosen to avoid contestation between actors in the internal movement. Internal consolidation of movements is needed so that social movements gain strong legitimacy from the public.

In addition, the \#GejayanCalling action is carried out on an ongoing basis. From \#Gejayan Calling on September 23, 2019, and \#Gejayan Calling on September 30, 2019 actually showed the consistency of social movements as intermediary actors. As an intermediary actor, \#Gejayancalling calls various mobilization and organization of actions to be carried out, both internally and externally. Action mobilization is carried out for example through propaganda on social media, as well as utilizing communication networks between social groups in Yogyakarta. The 
strength of amplifying movement issues on social media (such as strengthening hashtags on Twitter, spreading flyers, and building propaganda through opinions) makes \#GejayanCalling able to organize mass actions of various social groups. Likewise the organization of actions is carried out by strengthening the study of issues and mapping of movements, which involve various movement groups. This can be seen for example from the \#GejayanCalling part I which successfully mobilized large numbers of masses. Although the \#GejayanCalling part II, declining of the mass of action, the consolidation of the movement was even more organized than \#GejayanCalling part I.

The same statement was conveyed by another informant who was also involved as a member of the People's Alliance of Movement that:

"It is true, there has been a decrease in the number of times compared to the \#GejayanCalling action part 1, but behind that, in \#GejayanCalling II, the action was more organized than the first. Also, in the \#GejayanCalling II, many new actors from various segments came in with different issues. So that his demands increased from 7 to 9 demands " (interview with Ilham on 29 October 2019).

The high number of action periods in \#GejayanCalling I and then experience declining in \#GejayanCalling II can be explained with the following reasons. \#GejayanCalling I was able to mobilize a large mass of action because it succeeded in utilizing propaganda on social media and the reaction of "collective anger" towards the government, which at that time arose spontaneously in various regions. Mainly related to the Corruption Eradication Commission (KPK) Law which is considered more permissive towards politicians. The drawback of \#GejayanCalling I is internally less well organized. Instead, it is different from the \#GejayanCallimg II. Declining of the mass of action caused the objective situation at that time, namely the majority of students on various campuses were conducting Midterm Exams and the decline in social movement tension in various regions also affected the spirit of the mass of action. The advantage, from the internal consolidation of the movement, the \#GejayanCalling II action was better organized because it was prepared by a movement group from various issues of concern. That is why the demands of the movement increased because it involved various groups with representations of different issues.

The neatly organized \#GejayanCalling II action also demonstrates the sustainability of social movements which should be appreciated, although at the same time instructions from the Ministry of Research and Technology and a number of higher education leaders were issued to ban demonstrations. In addition, although there was a general declining number of action periods, there was an objective condition namely the shooting of students from the Muhammadiyah Student Association (IMM) in Kendari which then triggered the mobilization of most students of the Muhammadiyah University of Yogyakarta (UMY) compared to previous actions. Departing from this situation, the sustainability of the 
\#GejayanCalling action must then be read not only as a social movement, but as an informal means to demonstrate the power of public legitimacy to various government political decisions. In other words, social movements must be positioned as another way of channeling public legitimacy amid the closure of formal political channels such as political parties and other power institutions.

In other contexts, as an intermediary actor, social movements are certainly appear as an informal institution that works to gather various social forces from various actors, groups, through a number of consolidations to mobilize the movement. In these works, the social movement then manages a number of discourses that are claimed to represent the public interest, and communicates them with various group segments in the internal movement. It is the consolidation of a number of interests from various segments of the movement that makes the social movement then appear to legitimize itself as a representation of the public interest. This then makes social movements different from political parties.

\section{\#GejayanCalling as a Model of Public Legitimacy}

Generally, the two lines of public legitimacy, namely political parties or government and social movements are positioned vis a vis by claiming one of them is the most legitimized by the public. Political parties usually claim to gain strong legitimacy from the people because they are elected through general elections and entered into the political structure. Conversely, social movements that assume have gained legitimacy because they are outside the political system and stand together with civil society. In other words, resistance from social movements against government, is resistance from outside the political system, exactly where civil society is located (Hikmawan, 2020).

This paper does not want to position the two in the opposite direction, in addition to sharpening endless claims and long debates, nor does it want to lead the public to become a-political in looking at social movements or political parties. In other words, both social movements and political parties must be seen as political phenomena. We prefer to place them both as political channels for civil society, so that both of them have the right to be said to have public legitimacy as long as they are in line with public interests.

As for social movements, both NGOs, mass organizations and social groups, always use informal political channels to gain public legitimacy by responding to government policies, through demonstrations, protests and social actions. It is different, for example, with political parties that use formal political channels to gain public legitimacy, through elections, and political decision making in government. Social movements are a way of responding to political work or government policy from outside the political system, because of the closed access to formal political institutions. Thus, as an intermediary actor, social movements always appear and consolidate the public interest in their internal movements before being pressured to the government. Arena of consolidation in the internal movement itself, it usually 
involves a variety of actors, and interests. Although it is closely linked with the government above and civil society at the lower level, the presence of social movements only responds to the political situation that occurs in both. The response to civil society is usually in the form of aggregation of public interests, as well as mobilization, while the response to the government is in the form of political resistance or pressure.

To separate social movements as separate spaces from the state and civil society, then social movements can be differentiated into, social action (Giddens, 2013) and community resistance against elite authorities (Tarrow, 1998). In the context of the \#GejayanCalling action, the social movement was included as an opposition to the government elite. Thus, \#GejayanCalling summons as civil society representatives who question the public legitimacy of a number of government decisions. In other words, the government policy is not legitimate, not because the procedure is for the government not to make decisions, but because the political mechanism used by the government to decide on a number of these policies is not in favor of the public interest.

The emergence of social movements such as \#GejayanCalling is part of an effort to protect the legitimacy of the public, so as not to be "hijacked" by the government. Conversely, when the government responds to the demands of the social movement, it indicates that the government and social movements are fighting over public legitimacy. The government claims to have gained legitimacy through the political mechanism it has taken, on the other hand social movement groups consider obtaining legitimacy from the public because it stands together with civil society who are disadvantaged by the decision.

This claim of legitimacy continues and usually leads to a contestation of who is most legitimated. So as to avoid scrambling for legitimacy, what can be taken, both by social movements and the government, is to engage with civil society. In this case, the relation of social movements and the government should together strengthen public interests. That way, what the social movement group and the government do is supported by strong public legitimacy.

\section{Conclusion}

\#GejayanCalling Movement was born as a response to crisis legitimacy related to the failure of the government in carrying out the functions of the state and realizing the welfare of society. The failure is mainly on aspects of policy formulation that are not accommodative in responding to public problems. This policy product on the KPK considered to weaken the anti-corruption organization was the starting point for a number of protests initiated by the public, especially among students. The \#GejayanCalling Movement is a protest of Yogyakarta students who also involved various elements of civil society as an effort to claim public space that has been thick with the interests of the political elite and the oligarchs. 
The \#GejayanCalling movement success in attracting thousands of student masses onto the streets is proof that the country is truly at a crossroads towards the decline of democracy. The political situation opened up opportunities for all student activists to form alliances, protest. This student activist consists of various elements of the organization, community and campus with all issues that are trying to be raised to the public. The process of negotiation, compromise and consolidation between activists makes the \#GejayanCalling to be massive and avoids the possibility of contestation and movement between activists who are wrapped in sectoral egos. The presence of social media has become one of the instruments that is very effective in mobilizing the masses. This confirms that \#GerjayanCalling is a social movement not a collective action because everything is by design, well planned and issues are contested to then produce seven demands on \#GejayanCalling I and expand into nine demands on \#GejayanCalling II. Even though \#GejayanCalling II experienced a decline in the number of mass actions, the mobilization and organizational arrangement of the movement was more tidy and planned.

Because \#GejayanCalling is a social movement that is an alliance not a formal organization, then the continuation of this movement after the wave of massive demonstrations a few months ago cannot be predicted. Political situation and momentum become one of the references when this movement will be revived at any time. What is clear, social media is a means for movement activists to care for the \#GeyajanCalling movement in order to keep guarding the spirit of reform and democratization of the undermining oligarchs and corrupt elites.

\section{References}

Ahmed, A.K. (2019). \#RhodesMustFall: How a Decolonial Student Movement in the Global South Inspired Epistemic Disobedience at the University of Oxford. African Studies Review. doi:10.1017/asr.2019.49

Chamsy El-Ojeili \& Patrick Hayden. (2006). Critical Theories of Globalization Basingstoke \& New York: Palgrave Macmillan.

Chamadi, M.R., Sumantri, R.A. (2019). Tipologi Gerakan Mahasiswa Melalui Organisasi Mahasiswa Islam Di Purwokerto. Titian: Jurnal Ilmu Humaniora, 3 (02), 241-259.

Chan, Che-po. (2016). Post-Umbrella Movement: Localism and Radicalness of the Hong Kong Student Movement. Contemporary Chinese Political Economy and Strategic Relations. 2. 885-908.

Bellei, C., Cristian Cabalin \& Víctor Orellana. (2014). The 2011 Chilean student movement against neoliberal educational policies. Studies in Higher Education, 39:3, 426-440, DOI: 10.1080/03075079.2014.896179 
Gencoglu, F \& Yarkin, D.B (2019) The student movement in Turkey: a case study of the relationship between (re)politicization and democratization, Journal of Youth Studies, 22:5, 658-677, DOI: 10.1080/13676261.2018.1535170

González, Felipe. (2017). Collective Action in Networks: Evidence from the Chilean Student Movement. Retrived from http://dx.doi.org/10.2139/ssrn.2943760

Giddens, A. (2013). The Constitution of Society: Outline of the Theory of Structuration: Wiley.

Giddens, A. (1993). Sociology. Oxford: Polity Press

Heywood, Andrew. (2014). Politik. Jakarta: Pustaka Pelajar

Hikmawan, M. D. (2020). Consensual democracy: A challenge for differentiated citizenship. International Journal of Innovation, Creativity and Change, 11(2), 380 396.

Jazimah, Ipong. (2013). MALARI: Studi Gerakan Mahasiswa Masa Orde Baru. Agastya: Jurnal Sejarah Dan Pembelajarannya. 3. 10.25273/ajsp.v3i01.902.

Lipset, S Martin (1960). Political Man: The Social Bases of Politics. Doubleday \& Company, Inc., Garden City, New York.

Luescher, T., Loader, L., \& Mugume, T. (2016): \#FeesMustFall: An Internet-Age Student Movement in South Africa and the Case of the University of the Free State, Politikon, DOI: 10.1080/02589346.2016.1238644

McAdam, D., Tarrow, S., \& Tilly, C. (2001). Dynamics of Contention (Cambridge Studies in Contentious Politics). Cambridge: Cambridge University Press. doi:10.1017/CBO9780511805431

Michael Hardt \& Antonio Negri. (2004). Multitude: War and Democracy in the Age of Empire. London: Penguin.

Nasional.kompas.com. (2019). Gelombang Protes Mahasiswa, Menristekdikti Ancam Beri Sanksi Rektor?. Online: Retrived from https://nasional.kompas.com/ read/2019/09/26/12573121/gelombang-protes-mahasiswa-menristekdiktiancam-beri-sanksi-rektor?page $=$ all

Sharma, Prashant. (2014). From India Against Corruption to the Aam Aadmi Party: Social Movements, Political Parties and Citizen Engagement in India. IDEA.

Singh, Rajendra. (2010). Gerakan Sosial Baru. Yogyakarta: Resist Book.

Surbakti, Ramlan. (1992). Memahami Ilmu Politik. Jakarta: Gramedia Widjaya Sarana.

Tilly, Charles. (2004). Social Movements, 1768-2004. London: Paradigm.

Tarrow, S. (1998). Social Movements and Contentituous Politics. Cambridge : Cambridge University Press. 
Tarrow, S. (2011). Power in Movement: Social Movements and Contentious Politics (Cambridge Studies in Comparative Politics). Cambridge: Cambridge University Press. doi:10.1017/CBO9780511813245

Taufik, M. (2014). Resistensi Gerakan Mahasiswa Terhadap Kapitalisasi Pendidikan (Studi Organisasi Eksternal Kampus Di Unesa). Paradigma, 2 (3), 1-13.

Thierry Luescher, Lacea Loader \& Taabo Mugume (2016): \#FeesMustFall: An Internet-Age Student Movement in South Africa and the Case of the University of the Free State, Politikon, DOI: 10.1080/02589346.2016.1238644

Usman, Sunyoto. (1999). Arah Gerakan Mahasiswa: Gerakan Politik Ataukah Gerakan Moral?. Jurnal Ilmu Sosial dan Ilmu Politik, 3 (2), 146-163.

Willson, J. (1973). Introduction to Social Movements. New York : Basic Books 